\title{
Immunoelectron-Microscopic Localization of Peptidergic Nerve Fibers around Lymphatic Capillaries in the Rat Liver*
}

\author{
Yuko Ito, Sumiko Magari and Masahiro SaKanaka \\ Department of Anatomy, Osaka Medical College, Takatsuki, Osaka, Japan
}

Received December, 27, 1989

Summary. The localization of neuropeptide Y (NPY)-, substance $P$ (SP)- and calcitonin gene-related peptide (CGRP)-containing nerve fibers around lymphatic capillaries (initial lymphatics) in the interlobular connective tissue of the rat liver was investigated by preembedding immunoelectron-microscopy. Nerve terminals with NPY were frequently seen in close apposition to the abluminal surface of lymphatic endothelium. A small number of NPY fibers without a glial (Schwann cell) covering at the tip ran toward lymphatic capillaries in the interlobular connective tissue. Nerve fibers immunoreactive for SP were present within unmyelinated fiber bundles that ran close to lymphatic capillaries in the interlobular connective tissue. Besides these immunoreactive nerve fibers, many of which appeared to pass through the subendothelial regions of lymphatic capillaries, scattered SP nerve endings were seen in areas contiguous to lymphatic endothelium. CGRP terminals were rarely found around lymphatic capillaries, although nerve fiber bundles containing CGRP components traversed close to some lymphatic capillaries. These findings suggest that NPY and SP, if released from nerve terminals into the subendothelial areas of adjacent lymphatic capillaries, are more likely to affect the metabolic activity of lymphatic endothelium and the flow (or formation) of lymph than CGRP. SP and CGRP, as possible mediators of sensory transmission, might be involved in the conveyance of information on the hydrostatic pressures of hepatic lymphatics and surrounding tissue fluid to the central nervous system.

The flow of lymph is augmented by 1) an increase in blood capillary permeability, 2) an increase in hydro- static pressure, or 3) a decrease in colloidal osmotic pressure of the blood plasma (RUSZNYÁK, FÖLDI and SZABÓ, 1967; FAWCETT, 1986). In addition to the above factors facilitating the passive transport of lymph, several endogenous substances, such as prostaglandin $\mathrm{I}_{2}$ and bradykinin may be considered to regulate lymph flow by acting directly not only on collecting lymphatics with smooth muscle (MANNHEIMER et al., 1980; AZUMA, OHHASHI and RODDIE, 1983; SinZINGER, KALIMAN and MANNHEIMER, 1984, 1986), but also on lymphatic capillaries (initial lymphatics) (UNTHANK and HoGAN, 1987; ITO, MAGARI and SAKANAKA, 1989).

Neural components also participate in the active control of lymph flow on the basis of previous physiological studies dealing with the effects of neurotransmitters or neuromodulators on the contractility of collecting lymphatics (OHHASHI, KOBAYASHI and TSUKAHARA, 1982; McHAle and PodDie, 1983; OHHASHI, OLSCHOWKA and JOCOBOWITZ, 1983; OHHASHI and AZUMA, 1984, 1986; AlLEN, IGGULDEN and MCHALE, 1986; AlLEN and MCHALE, 1986). Although the smooth muscle layer of collecting lymphatics appears to be a main target of the neural components (OHHASHI, KAWAI and AZUMA, 1978; RUSSEL, ZIMMERMAN and MIDDENDORF, 1980; OHHASHI, KOBAYASHI and TSUKAHARA, 1982; MCHALE, and PoDDIE, 1983; OHHASHI, OLSCHOWKA and JACOBOWITZ, 1983; OHHASHI and AZUMA, 1984, 1986; Allen, IGGULDEN and MCHAle, 1986; Allen and MCHALE, 1986), the presence of many nerve fibers around lymphatic capillaries which lack smooth muscle in the hepatic inter-

\footnotetext{
*This work was partly supported by a grant-in-aid for scientific research (63304029) from the Ministry of Education, Science and Culture, Japan.
} 
lobular connective tissue, as demonstrated by conventional electron-microscopy (MAGARI, FUJIKAWA and NishI, 1979; MAGARI et al., 1979; MAGARI, 1983), raises the possibility of lymphatic endothelium as another target of the nervous tissue. If so, nerve fibers may affect lymphatic endothelial activity or contractility together with the above prostaglandin $\mathrm{I}_{2}$ and bradykinin. Our recent immunohistochemical study showed that nerve terminals with neuropeptide Y (NPY)-like immunoreactivity are frequently located in proximity to the endothelium of hepatic blood vessels as well as in the vicinity of the smooth muscle layer of the vessels (INOUE et al., 1989), suggesting a possible interaction between NPY and blood vessel endothelium. This finding encouraged us to examine with preembedding immunoelectron-microscopy the distribution of vasoactive substance-mediated nerve fibers around lymphatic capillaries in the interlobular connective tissue of the rat liver (CHAPPLE et al., 1980; Ellsworth, Gregory and Newell, 1983; BRANDT et al., 1984; ZUCKER et al., 1988).

\section{MATERIALS AND METHODS}

Ten Wistar male rats weighing 150 to $200 \mathrm{~g}$ were used in this study. All animals were housed at constant temperature $\left(20^{\circ} \mathrm{C}\right)$ in a $12-12 \mathrm{~h}$ light-dark cycle and given food and water ad libitum. The animals were deeply anesthetized with pentobarbital and perfused transcardially, first with $100 \mathrm{ml}$ of phosphate buffered saline (PBS), then with $250 \mathrm{ml}$ of $4 \%$ paraformaldehyde- $0.05 \%$ glutaraldehyde- $0.2 \%$ picric acid in $0.1 \mathrm{M}$ phosphate buffer $(\mathrm{PB})(\mathrm{pH}$ 7.4) (SOMOGYI and TAKAGI, 1982), and finally with $50 \mathrm{ml}$ of PBS. Following the perfusion, the liver was quickly removed and cut into small tissue blocks, which were sectioned at $60 \mu \mathrm{m}$ with a Dosaka microslicer. The sections were washed five times with PBS (10 min for each washing) and kept in a PBS solution containing $0.1 \%$ gelatin and $0.005 \%$ hydrogen peroxide for 20 min to suppress endogenous peroxidase activity in the tissue. After a brief rinse in PBS, the sections were processed for the unlabeled antibody peroxidase-antiperoxidase (PAP) method (STERNBERGER, 1979) with the use of antisera against neuropeptide Y (NPY) (Amersham) (INOUE et al., 1989), calcitonin gene-related peptide (CGRP) (Amersham) and substance P (SP) (YAMASAKI et al., 1984), which showed no significant crossreactivity with other related peptides. The sections were postfixed with $1 \%$ osmium tetraoxide in $0.1 \mathrm{M} \mathrm{PB}(\mathrm{pH} 7.4)$, dehydrated in a graded series of ethanol while being stained with $1 \%$ uranyl acetate in $70 \%$ ethanol, transferred to propylene oxide and embedded in an epoxy resin. Ultrathin sections from the interlobular connective tissue regions were made with a Porter-Blum MT 2B ultramicrotome and examined in Hitachi H-300 and H-800 electron-microscopes.

Control sections were first incubated with NPY, CGRP and SP antisera absorbed with an excess of the homologous antigens, and then processed as described above.

\section{RESULTS}

On the basis of the conventional electron-microscopic findings of FUJIKAWA and MAGARI (1975), MAGARI, FUJIKAWA and NiSHI (1979), MAGARI et al. (1979) and MAGARI (1990), lymphatic capillaries (initial lymphatics) within the interlobular connective tissue were easily identified even in tissue sections fixed with a small amount of glutaraldehyde. They frequently exhibited a thick endothelium that contained various types of vesicles, phagosomes and lysosomes (MAGARI, 1987) (Figs. 1, 2). Protrusion of the thick endothelial cell bodies into the lumen sometimes made the lumen appear narrower (Figs. 1,2) than the thin-walled lymphatic capillaries which were also seen in the liver. Some lymphatic lumens contained electron-dense flocculent material in areas close to the endothelium or in the entire region (Figs. 1-3), although some of the electron-dense materials might represent substance P-like immunoreactivity in lymph (JoNSSON et al., 1986). The processes of lymphatic endothelial cells frequently formed typical interdigitations with occasional desmosome-like structures, as described by MAGARI, FUJIKAWA and NisHI (1979). The abluminal surface of the lymphatic endothelium was occasionally endowed with halfdesmosome-like structures (Fig. 2a) and/or small cytoplasmic projections (Figs. 2a, 3). Subendothelial anchoring filaments in contact with the halfdesmosome-like structures or the abluminal surface of the endothelial cells could also be markers for the identification of lymphatic capillaries (Figs. 2a, 4b). Thus, the satisfactory preservation of lymphatic ultrastructural features, together with the presence of perilymphatic collagen fiber bundles forming the so-called "pre-lymphatic pathway" (MAGARI, FUJIKAWA and NisHI, 1979) (Figs. 1, 2b, 3-5), enabled us to examine the interrelations of the lymphatic capillaries with the vasoactive peptides which were localized exclusively to unmyelinated nerve fibers.

Nerve fibers with NPY-like immunoreactivity 


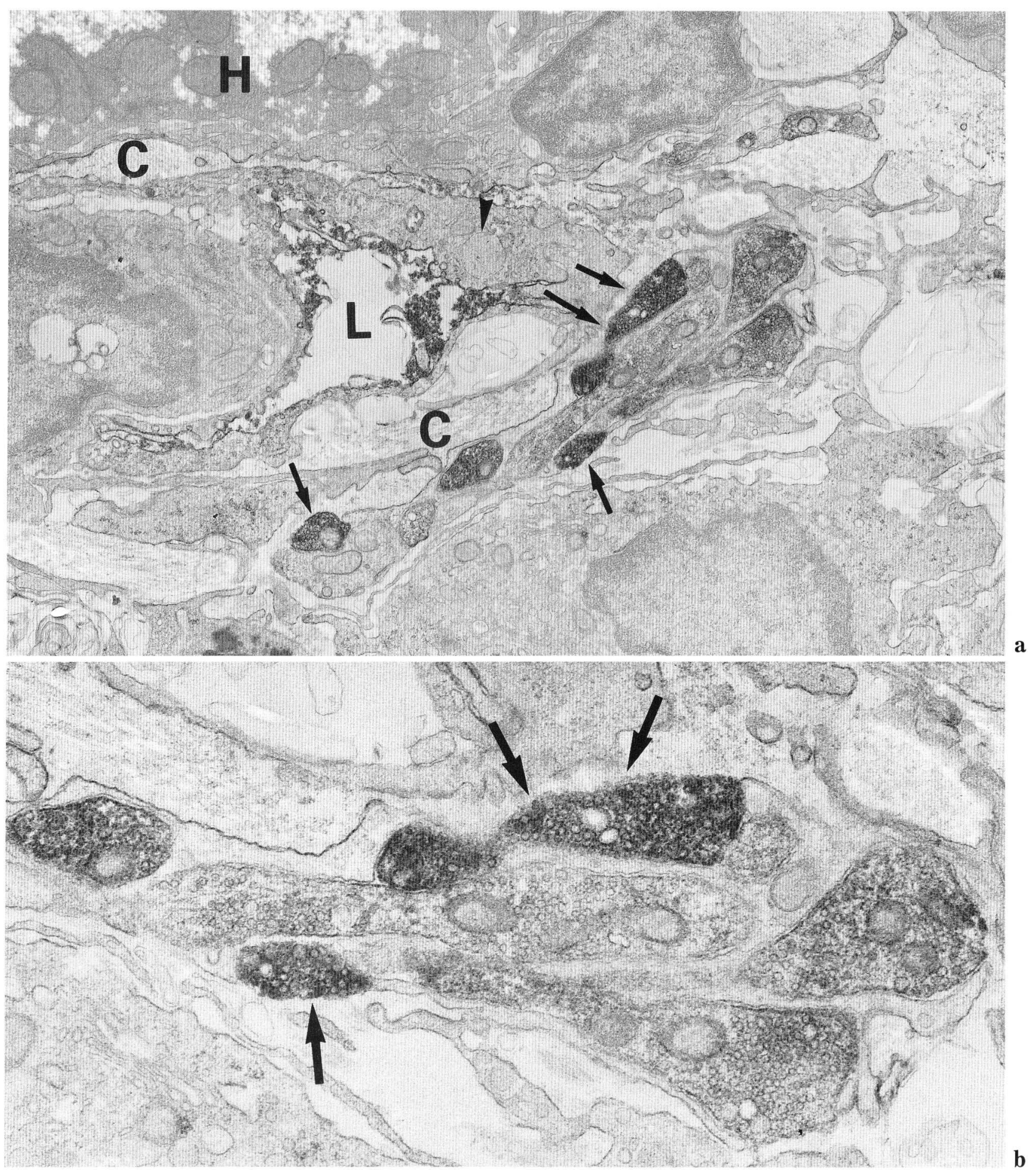

Fig. 1. Electronmicrographs showing NPYI terminals (arrows) that encircle a lymphatic capillary at low magnification (a) and at high magnification (b). The lumen of the lymphatic capillary appears narrow because of protrusion of the thick endothelium into the lumen. Note a lysosome in the endothelium (arrowhead). $C$ collagen bundle in the interlobular connective tissue, $H$ hepatocyte, $L$ lumen of a lymphatic capillary. a: $\times 11,000$, b: $\times 24,000$ 


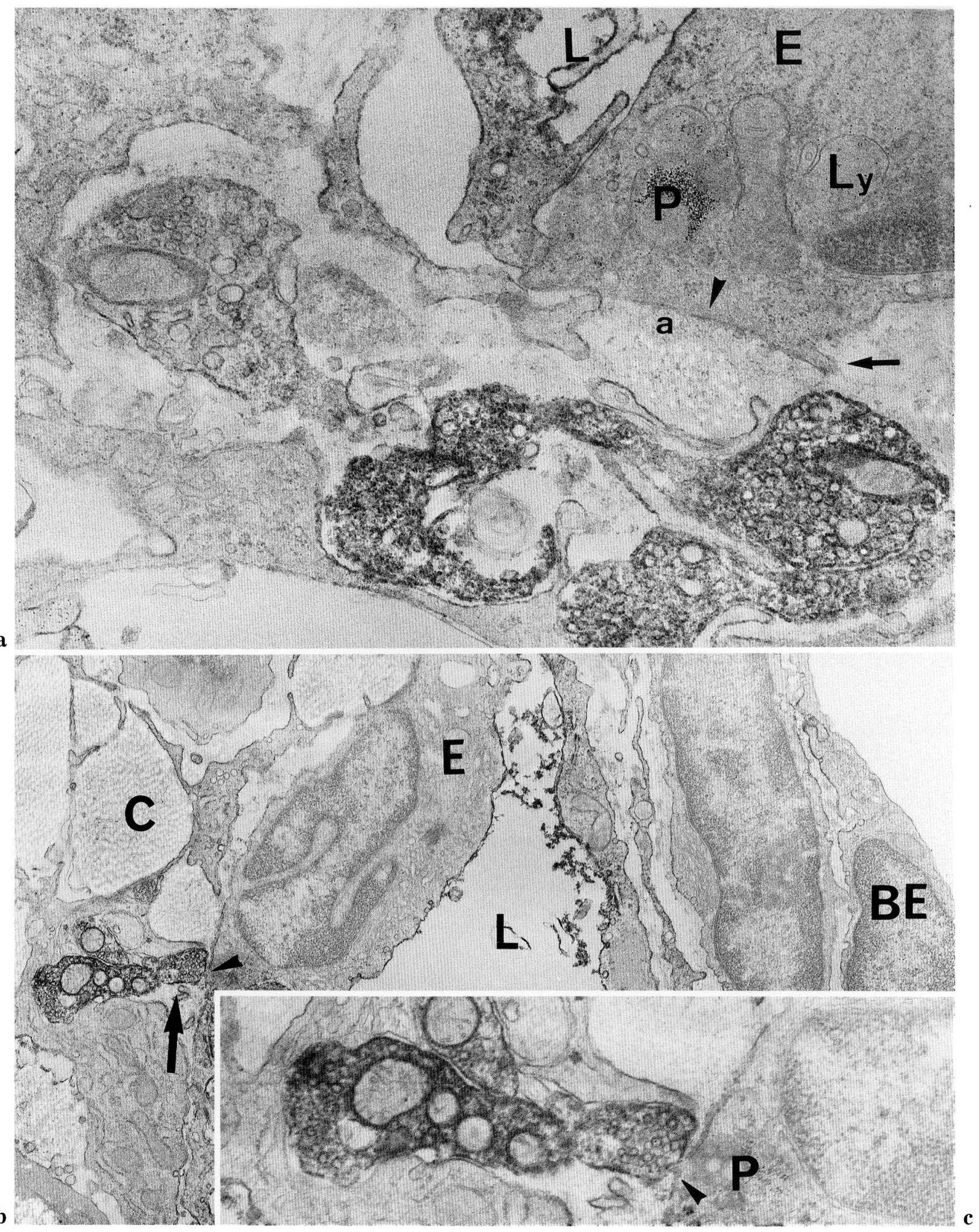

Fig. 2. Legend on the opposite page. 
(NPYI) were frequently observed around lymphatic capillaries in the interlobular connective tissue (Figs. $1,2)$. They sometimes seemed to encircle the lymphatic endothelium, while losing gradually their glial (Schwann cell) investment (Figs. 1, 2). Some of the NPYI fibers (possibly terminals) were devoid of a glial covering on the side facing the abluminal surface of the lymphatic endothelium (Fig. 1). The NPYI terminals were occasionally accompanied by nerve fibers devoid of or less immunoreactive for NPY (Fig. 1). A small number of NPYI terminals was closely apposed to the abluminal projections of lymphatic endothelial cells (Fig. 2a). There were also NPYI fibers that ran toward lymphatic capillaries. Some of these immunoreactive fibers lost glial (Schwann cell) sheaths in proximity to the abluminal surface of the lymphatic capillaries (Fig. 2b, c). In many cases, nerve fibers or terminals immunoreactive for NPY were filled with numerous clear vesicles and scattered dense cored vesicles. No apparent membrane specialization was seen between NPYI terminals and lymphatic endothelium.

Nerve fibers exhibiting substance P-like immunoreactivity (SPI) were present within unmyelinated fiber bundles that ran between lymphatic capillaries and blood vessels in the interlobular connective tissue. Some nerve fiber bundles with SPI were associated more closely with lymphatic capillaries than with blood vessels. Many SPI fibers in the nerve fiber bundles of the liver seemed to pass through the subendothelial areas of lymphatic capillaries (Fig. 3). Scattered SPI fibers (possibly terminals) not covered with glial sheaths were also identified beneath the endothelium of lymphatic capillaries (Fig. 4). Nerve fibers immunoreactive for SP appeared to have fewer clear vesicles than NPYI fibers (Figs. 1-4).

Nerve fibers with calcitonin gene-related peptidelike immunoreactivity (CGRPI) were found in unmyelinated fiber bundles within the interlobular connective tissue (Fig. 5). Some nerve fiber bundles containing CGRPI components were seen in the subendothelial areas of lymphatic capillaries, and others ran along the abluminal surface of lymphatic endothelium (Fig. 5). In many of the electronmicrographs examined, there were intervening connective tissue elements and/or glial (Schwann cell) processes between the CGRPI fibers and lymphatic capillaries.

Pretreatment of NPY, SP and CGRP antisera with an excess of the homologous antigens abolished all immunoreactions.

\section{DISCUSSION}

Previous studies have shown that hepatic NPYI fibers arise from para- and prevertebral sympathetic ganglia (INOUE et al., 1989), and SPI and CGRPI fibers from peripheral sensory ganglia (SASAKI et al., 1984, 1986). In agreement with these findings, nerve fibers with NPYI showed a distribution pattern different from that of SPI and CGRPI fibers around hepatic lymphatic capillaries. It is worth noting that nerve fibers immunoreactive for SP and CGRP do not have identical locations around the lymphatic capillaries. Taken together, the three neuropeptides examined in this study may subserve different functions in the hepatic lymphatic system. In support of this, some NPYI fibers contain more numerous clear vesicles than SPI fibers around hepatic lymphatic endothelium. Although the exact sites of neuropeptide release and the mechanisms underlying its liberation from nerve fibers around the hepatic lymphatic capillaries are clearly beyond the scope of this report, the functional implications of our experimental results are discussed.

Lymphatic endothelium has been thought to play a pivotal role in the regulation of lymph formation and/or flow (LEAK and BURKE, 1966, 1968; LEAK, 1976; HOGAN and UNTHANK, 1986). When the endothelium is damaged, even collecting lymphatics with a smooth muscle layer may not completely respond to exogenous stimuli that are mainly directed to smooth muscle cells (OHHASHI, KaWAI and AzUMA, 1978; OHHASHI, OlschOWKA and JACOBOWITZ, 1983; OHHASHI and AZUMA, 1984, 1986) (Dr. T. OHHASHI, personal communication). The importance of lym-

Fig. 2. a. Electronmicrograph showing NPYI fibers (possibly terminals) devoid of a glial (Schwann cell) covering around a lymphatic capillary. Note that they are in close association with an abluminal small projection of the lymphatic endothelial cell (arrow). Note a possible half-desmosome in the abluminal surface of the endothelial cell (arrowhead). $E$ endothelial cell of a lymphatic capillary, $L$ lumen of a lymphatic capillary, $a$ anchoring filaments, $L y$ lysosome, $P$ phagosome. $\times 32,000$. b and c. Electronmicrographs showing NPYI terminals (arrow) just beneath the endothelium $(E)$ of a lymphatic capillary at low magnification (b) and at high magnification (c). Note that one of the immunoreactive terminals losts glial (Schwann cell) investment in proximity to the abluminal surface of the lymphatic capillary (arrowheads). BE endothelial cell of a portal vein branch. b: $\times 12,000, c: \times 31,000$ 

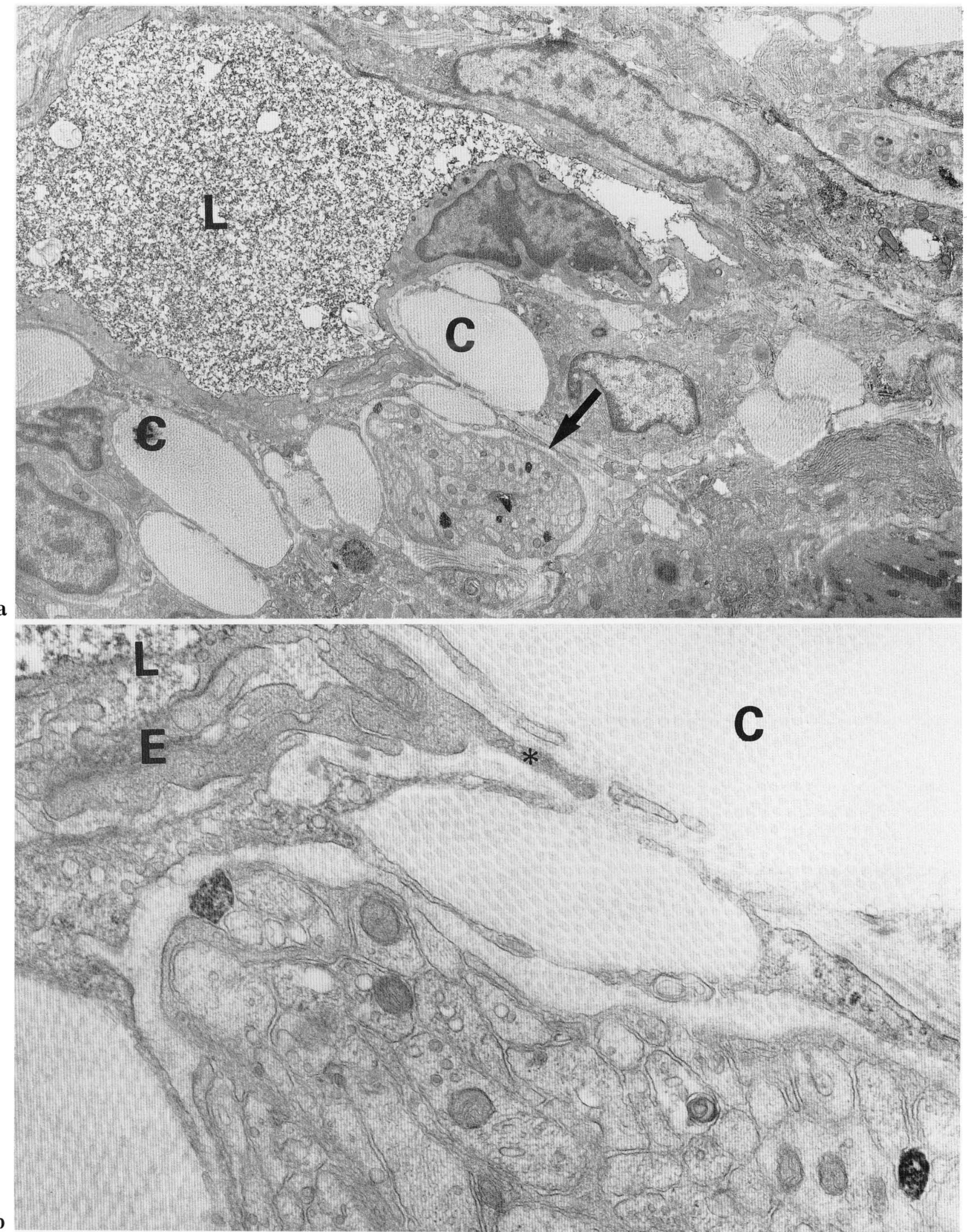

Fig. 3. Legend on the opposite page. 
phatic endothelium appears to be further reinforced by the immunohistochemical demonstration of bioactive substances (prostaglandin $\mathrm{I}_{2}$ synthase- and von Willebrand Factor-like materials) in lymphatic endothelial cells (MANNHEIMER et al., 1980; SinZINGER, KAliman and MANNHEIMER, 1984; Svanholm, NiELSTEN and HAUGE, 1984; NAGEL et al., 1985; SinZINGER, KALIMAN and MANNHEIMER, 1986; ITO, MAGARI and SASAKI, 1989; MAGARI, ITO and SAKANAKA, 1989) and by the finding of bradykinin-induced modulation of initial lymphatic contractility (UNTHANK and HoGAN, 1987). The present study showed that NPYI and SPI fibers with a terminal-like appearance, but not CGRPI fibers, are located close to the endothelium of hepatic lymphatic capillaries, although they are apparently fewer than those subjacent to the endothelium of hepatic blood vessels (INOUE et al., 1989). Therefore NPY and SP, if diffusely released from the nerve terminal-like structures into the subendothelial areas of adjacent lymphatic capillaries, are more likely than CGRP to affect the metabolic activity and/or lymph formation of lymphatic endothelium. It is also plausible that the SPI nerve system is activated under some pathological conditions to participate in the occurrence of lymphedema and/or wound healing (JoNSSON et al., 1983). Since substance $P$ and CGRP are putative mediators of sensory transmission (FURNESS et al., 1982; YAMAMOTO et al., 1983; UdDMAN et al., 1986; Goehler, Sternini and Brecha, 1988), nerve fibers

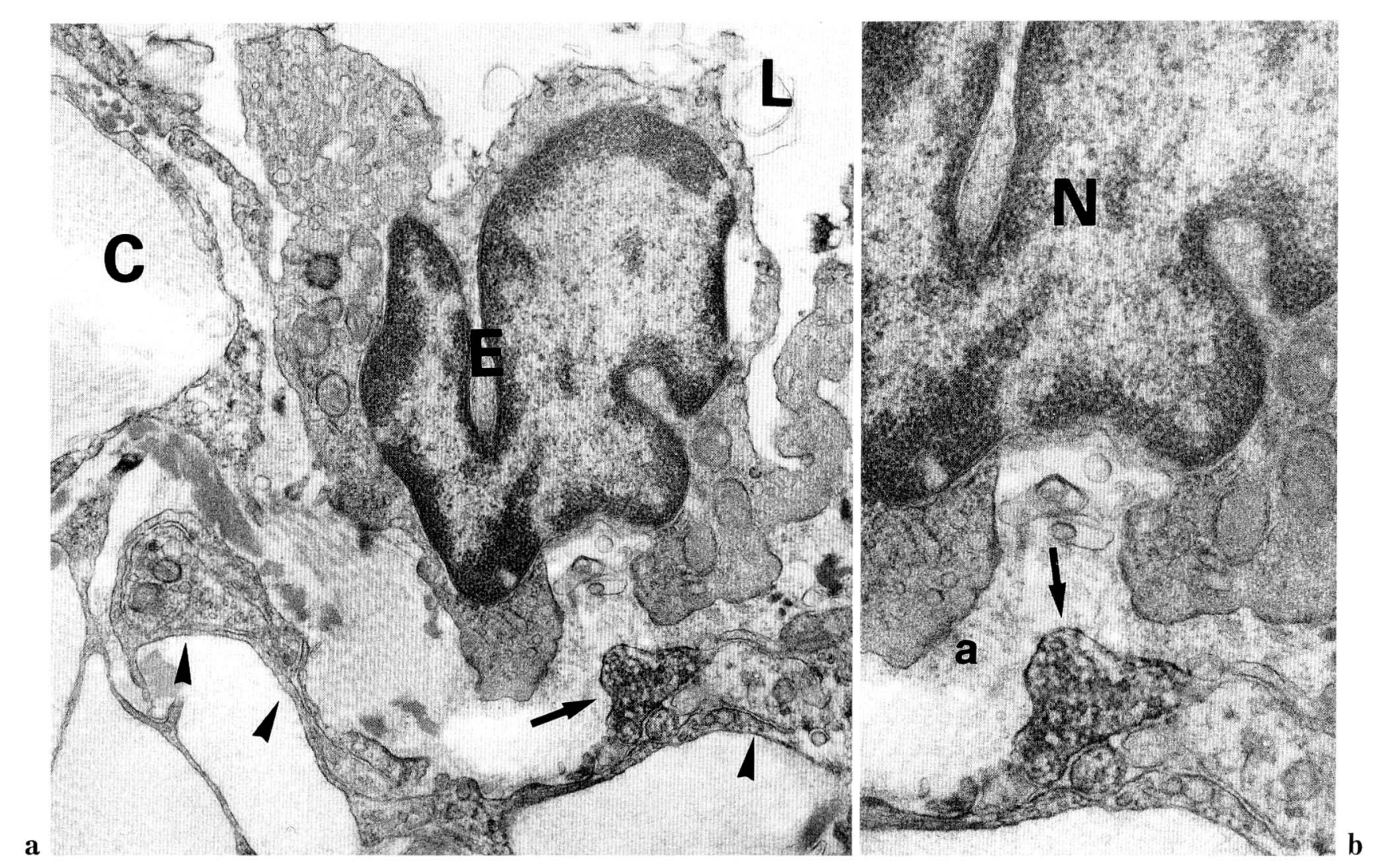

Fig. 4. Electronmicrographs showing a SPI terminal (arrow) and non-immunoreactive nerve fibers (arrowheads) around a lymphatic capillary at low magnification (a) and at high magnification (b). $a$ Anchoring filaments, $C$ collagen bundle in the interlobular connective tissue, $E$ endothelial cell of a lymphatic capillary, $L$ lumen of a lymphatic capillary, $N$ nucleus of an endothelial cell. a: $\times 18,000, \mathrm{~b}: \times 30,000$

Fig. 3. Electronmicrographs showing an unmyelinated nerve fiber bundle with SPI components, which runs close to a lymphatic capillary (arrow) at low magnification (a) and at high magnification (b). An abluminal projection of the endothelial cell is indicated by an asterisk. $C$ collagen bundle in the interlobular connective tissue, $E$ endothelial cell of a lymphatic capillary, $L$ lumen of a lymphatic capillary. a: $\times 6,300, \mathrm{~b}: \times 28,000$ 


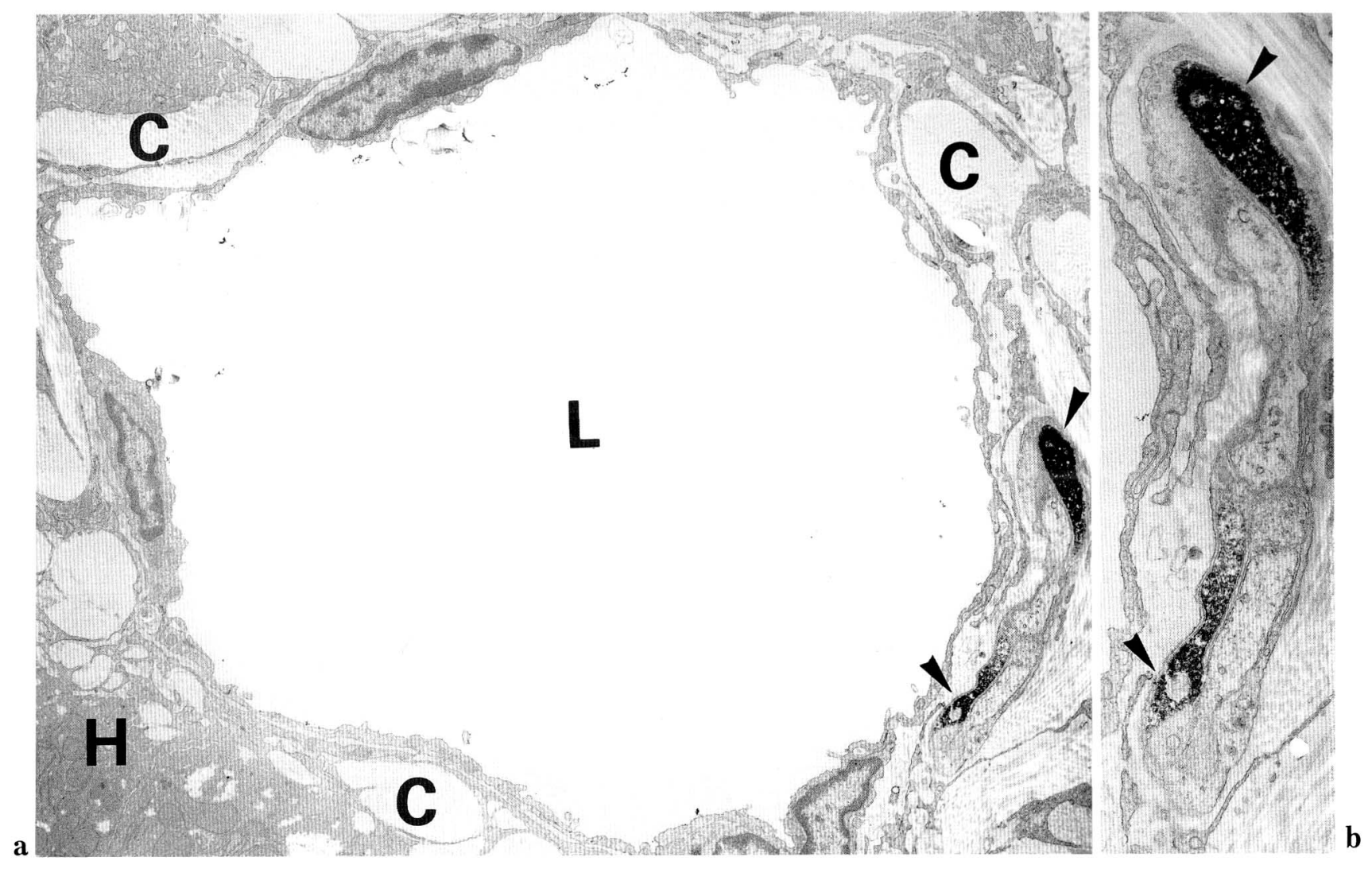

Fig. 5 a and b. Electronmicrographs showing an unmyelinated nerve fiber bundle with CGRPI components (arrowheads), which tranverses close to a lymphatic capillary at low magnification (a) and at high magnification (b). Note that there are intervening connective tissue elements and glial processes between the passing immunoreactive fibers and lymphatic capillary. $C$ collagen bundle in the interlobular connective tissue, $H$ hepatocyte, $L$ lumen of a lymphatic capillary. a: $\times 4,800, \mathrm{~b}: \times 10,000$

with these peptides may convey information on the hydrostatic pressures of the lymphatic capillaries and surrounding tissue fluid to the central nervous system (FURNESS et al., 1982; YAMAMOTO et al., 1983; UDD. MAN et al., 1986; GOEHLER, STERNINI and BRECHA, 1988). It remains to be determined if and how peptidergic nerve fibers interact with the bioactive substances produced in lymphatic endothelium.

In conclusion, the present study suggests that a certain population of chemically defined nerve fibers may act on initial lymphatic endothelium per se as well as regulating the contractility of collecting lymphatics through interaction with the smooth muscle layer (OHHashi, Kobayashi and TSUKahara, 1982; McHale and POdDIE, 1983; OhHashi, Olschowka and JaCoBowitz, 1983; OHhashi and AzUma, 1984, 1986; Allen, IGgulden and McHale, 1986; Allen and MCHALE, 1986).
Acknowledgements. The authors are grateful to Dr. Sadao SHIOSAKA, Department of Neuroanatomy at Osaka University Medical School for the generous provision of SP antiserum.

\section{REFERENCES}

Allen, J. M., H. L. A. IGgulden and N. G. McHale: $\beta$-adrenergic inhibition of bovine mesenteric lymphatics. J. Physiol. 374: 401-411 (1986).

Allen, J. M. and N. G. MCHale: Neuromuscular transmission in bovine mesenteric lymphatics. Microvas. Res. 31: 77-83 (1986).

Azuma, T., T. Оhнashi and I. C. Roddie: Bradykinininduced contractions of bovine mesenteric lymphatics. J. Physiol. (Lond.) 342: 217-227 (1983). 
Brandt, R., A. Dembińska-Kieć, R. Korbut, R. J. GrYGLEWSKI and J. NowaK: Release of prostacyclin from the human pulmonary vascular bed in response to cholinergic stimulation. Naunyn-Schmiedeberg's Arch. Pharmacol. 325: 69-75 (1984).

Chapple, D. J., G. J. Dusting, R. Hughes and J. R. VANE: Some direct and reflex cardiovascular actions of prostacyclin $\left(\mathrm{PGI}_{2}\right)$ and prostaglandin $\mathrm{E}_{2}$ in anaesthetized dogs. Brit. J. Pharmacol. 68: 437-447 (1980).

Ellsworth, M. L., T. J. Gregory and J. C. Newell: Pulmonary prostacyclin production with increased flow and sympathetic stimulation. J. Appl. Physiol. 55: 12251231 (1983).

FawcetT, W.: A textbook of histology. 11th ed. WB Saunders, Philadelphia-London-Toronto-Mexico CityRio de Janeiro-Sydney-Tokyo-Hongkong, 1986.

Fujikawa, K. and S. Magari: An electron microscopic study of the lymphatic capillaries in the interlobular connective tissue of the rabbit liver. Acta Anat. Nippon. 50: 129-137 (1975).

Furness, J. B., R. E. Papka, N. G. Della and M. Costa: Substance P-like immunoreactivity in nerves associated with the vascular system of guinea-pigs. Neuroscience 7: 447-459 (1982).

Goehler, L. E., C. Sternini and N. C. Brecha: Calcitonin gene-related peptide immunoreactivity in the biliary pathway and liver of the guinea-pig: distribution and colocalization with substance P. Cell Tiss. Res. 253: 145-150 (1988).

Hogan, R. D. and J. L. Unthank: The initial lymphatics as sensors of interstitial fluid volume. Microvas. Res. 31: 317-324 (1986).

Inoue, N., S. Magari, Y. Ito and M. Sakanaka: Distribution, possible origins and fine structures of neuropeptide $\mathrm{Y}$-containing nerve fibers in the rat liver. Brain Res. 493: 87-96 (1989).

Ito, Y., S. MagaRI and M. Sakanaka: Prostaglandin $I_{2}$ synthase in the lymphatic endothelium of rat liver as revealed by preembedding immunoelectronmicroscopy. Lymphology 22: 51-55 (1989).

Jonsson, C.-E., E. Brodin,, C.-J. Dalsgated and A. HaEgerstrand: Release of substance-P-like immunoreactivity in dog paw lymph after scalding injury. Acta Physiol. Scand. 126: 21-24 (1986).

LEAK, L. V.: The structure of lymphatic capillaries in lymph formation. Fed. Proc. 35: 1863-1871 (1976).

LEAK, L. V. and J. F. Burke: Fine structure of the lymphatic capillary and adjoining connective tissue area. Amer. J. Anat. 118: 785-809 (1966).

- : Electron microscopic study of lymphatic capillaries in the removal of connective tissue fluids and particulate substances. Lymphology 1: 39-52 (1968).

MAGARI, S.: Peripheral and autonomic nerves, sympathetic ganglia, and the lymphatic system. In: (ed. by) M. FÖLDI and J. R. CASLEY-SMITH: Lymphangiology. F. K. Schattauer Verlag, Stuttgart-New York, 1983 (p. 519533).
-: Comparison of fine structure of lymphatics and blood vessels in normal conditions and during embryonic development and regeneration. Lymphology 20: 189-195 (1987).

-: Hepatic lymphatic system: Structure and function. J. Gastroenterol. Hepatol. 5: (1990, in press).

MAGARI, S., K. FuJikawa and A. Nishi: Form, distribution, fine structure and function of hepatic lymphatics with special reference to blood vessels and bile ducts. Asian Med. J. 24: 254-270 (1979).

Magari, S., K. Fujikawa, Y. Mizutani and A. Nishi: Morphological studies on liver lymphatic. Lymphology 12: 14-17 (1979).

Magari, S., Y. Ito and M. Sakanaka: An immunoelectronmicroscopic study of von Willebrand Factor in the thoracic duct endothelium of rats. Lymphology 22: 76-80 (1989).

Mannheimer, E., H. Sinzinger, R. Oppolzer and K. SILBERBAUER: Prostacyclin synthesis in human lymphatics. Lymphology 13: 44-46 (1980).

Mchale, N. G. and I. C. Poddie: The effects of catecholamines on pumping activity in isolated bovine mesenteric lymphatics. J. Physiol. 338: 527-536 (1983).

Nagle, R., M. WitTe, C. WitTe and D. WAY: Factor VIII-associated antigen in canine lymphatic endothelium. Lymphology 18: 84-85 (1985).

Ohнashi, T. and T. Azuma: Sympathetic effects on spontaneous activity in bovine mesenteric lymphatics. Amer. J. Physiol. 247: H610-H615 (1984).

- : Pre- and postjunctional $\alpha$-adrenoreceptors at sympathetic neuroeffector junction in bovine mesenteric lymphatics. Microvas. Res. 31: 31-40 (1986).

Ohнashi, T., Y. KaWAI and T. AzUma: The response of lymphatic smooth muscles to vasoactive substances. Pflügers Arch. 375: 183-188 (1978).

OhHashi, T., S. Kobayashi and S. Tsukahara: Innervation of bovine mesenteric lymphatics: from the histochemical point of view. Microvasc. Res. 24: 377-385 (1982).

OhHaShi, T., H. A. Olschowka and D. M. Jacobowitz: Vasoactive intestinal peptide inhibitory innervation in bovine mesenteric lymphatics. Circulation Res. 53: 535538 (1983).

RUSZnYÁK, L., M. Földi and G. Szabó: Lymphatics and lymph circulation. 2nd ed. Pergamon Press, OxfordLondon-Edinburgh-New York-Toronto-Sydney-ParisBraunschweig, 1967.

Russel, J. A., K. Zimmerman and W. F. Middendorf: Evidence for $\alpha$-adrenergic innervation of the isolated canine thoracic duct. J. Appl. Physiol. 49: 1010-1015 (1980).

Sasaki, Y., T. Kamada, N. Hayashi, N. Sato, A. KaSA hara, H. Fusamoto, S. Shiosaka, M. Tohyama and Y. Shiotani: Immunohistochemical distribution of glucagon, substance $\mathrm{P}$ and vasoactive intestinal polypeptide in hepatic vasculature of the rat. Hepatology 4 : 1184-1189 (1984). 
Sasaki, Y., D. Hayashi, A. Kasahara, H. Matsuda, H. Fusamoto, N. Sato, C. J. Hillyard, S. Girgis, I. MacIntyre, P. C. Emson, S. Shiotani, M. Tohyama, Y. Shiotani and T. KAMAda: Calcitonin gene-related peptide in the hepatic and splanchnic vascular systems of the rat. Hepatology 6: 676-681 (1986).

Sinzinger, H., J. Kaliman and E. Mannheimer: Regulation of human lymph contractility by prostaglandins and thromboxane. Lymphology 17: 43-45 (1984).

: Effect of leukotrienes $\mathrm{C}_{4}$ and $\mathrm{D}_{4}$ on prostaglandin $\mathrm{I}_{2}$-liberation from human lymphatics. Lymphology 19: 79-81 (1986).

Somogyi, P. and H. Takagi: A note on the use of picric acid-paraformaldehyde-glutaraldehyde fixative for correlated light and electron microscopic immunocytochemistry. Neuroscience 7: 1779-1783 (1982).

Svanholm, H., K. Nielsten and P. Hauge: Factor VIII-related antigen and lymphatic collecting vessels. Virchows Arch., Pathol. Anat. 404: 223-228 (1984).

STERnBERGER, L. A.: Immunocytochemistry. 2nd ed. John Wiley \& Sons, New York, 1979.

Uddman, R., L. Edvinsson, E. Ekblad, R. Hakanson and F. SundLER: Calcitonin gene-related peptide (CGRP): perivascular distribution and vasodilatory effects. Regul. Pept. 15: 1-23 (1986).

Unthank, J. L. and R. D. Hogan: The effect of vasoactive agents on the contractions of the initial lymphatics of the bat's wing. Blood Vessels 24: 31-44 (1987).
Yamamoto, K., T. Matsuyama, S. Shiosaka, S. Inagaki, E. Senba, Y. Shimizu, I. Ishimoto, T. Hayakawa, M. Matsumoto and M. Tohyama: Overall distribution of substance P-containing nerves in the wall of the cerebral arteries of the guinea pig and its origins. J. Comp. Neurol. 215: 421-426 (1983).

Yamasaki, H., Y. Kubota, H. TakagI and M. Tohyama: Immunoelectron-microscopic study on the fine structure of substance-P-containing fibers in the taste buds of the rat. J. Comp. Neurol. 227: 380-392 (1984).

Zucker, I. H., M. J. Panzenbeck, S. Barker, W. TAN and M. A. HAJDU: PGI $_{2}$ attenuates baroreflex control of renal nerve activity by a vagal mechanism. Regulatory Integrative Comp. Physiol. 23: R424-R430 (1988).

Dr. Yuko ITO

Department of Anatomy

Osaka Medical College

2-7 Daigakumachi

Takatsuki, Osaka, 569 Japan

伊藤裕子

569 大阪府高梘市大学町 2-7

大阪医科大学

解剖学第一講座 